\title{
22. Resolving the current crisis in Fiji - a personal perspective
}

\section{Jioji Kotobalavu}

Public reaction to the military coup of 5 December 2006 has taken several forms. First, there has been a reaction from those who were directly and personally affected; the victims of the coup and the 'clean-up' campaign. These included members of the ousted Qarase government; high officials in the civil service, statutory bodies, public enterprises and other organizations who have lost their jobs; and members of the suspended Great Council of Chiefs (GCC). For them, the focus of attention is the legality of the coup and other subsequent actions.

The second group includes those who have not been personal victims of the coup, but who, nevertheless, feel strongly about the overthrow of an elected government. These are people who believe very deeply in democracy and the rule of law.

The third group includes those who are political supporters of deposed Prime Minister Qarase and his Soqosoqo Duavata ni Lewenivanua (SDL) government, mainly comprising Fijians who have condemned the coup.

Fourthly, there are those who were strongly opposed to what they perceived to be the Qarase government's racist policies. Many in this latter group are from the Indian and 'other' communities, who have expressed support for the new regime even though they are also concerned about democracy and the rule of law.

The focus of this chapter is on the reaction of the ordinary people, of all races and from all socio-economic backgrounds, who have been affected personally - not so much by the coup itself but by its consequences, especially the ensuing economic hardship that has affected people's daily lives. Like the earlier coups against elected governments (in May 1987 and May 2000), the 2006 coup has seriously undermined people's confidence about the future. There is a prevailing feeling of concern and uncertainty.

However, any commentary on the current situation, to be fair, has to acknowledge the sincere and determined efforts of interim Prime Minister Voreqe Bainimarama and his interim administration to restore normality, to prioritize law and order, to promote economic recovery, and to lay the groundwork for a better Fiji for all its citizens and multi-ethnic communities.

This chapter seeks to explain the situation in Fiji today, and make suggestions for consideration by those in authority. The suggestions are made in the hope 
that they will contribute to an approach which will enable Fiji to secure a peaceful, prosperous and coup-free future.

\section{The interim administration's aspirations}

On 5 December 2006, the commander of the Republic of Fiji Military Forces (RFMF), Commodore Voreqe Bainimarama, deposed the elected government of Prime Minister Laisenia Qarase and dismissed the country's parliament. This also ended Fiji's first venture into multiparty government - a form of government required under the constitution.

Interim Prime Minister Bainimarama duly announced a 'road map', based on a mandate from the President, which was to be regarded as the interim administration's mission statement. Its priorities included the maintenance of law and order and national security, the eradication of corruption, and the restoration of parliamentary government through elections 'after an advanced electoral office and systems are in place and the political and economic conditions are conducive to the holding of such elections' ${ }^{2}$

The interim administration implemented its own budget for 2007. It has introduced measures both to reduce the cost of government, and to create job opportunities in the public service for new graduates and school leavers. It has also embarked on a 'clean-up' campaign to rid the civil service, statutory authorities and public enterprises of mismanagement and corruption. An independent body, the Fiji Independent Commission Against Corruption (FICAC), has been established to spearhead this initiative. Building on its declared intention to improve relations with Fiji's neighbours and the international community, the interim administration has been holding consultations with important bilateral partners and multilateral organizations. It has entered into a broad understanding with the Pacific Islands Forum and with the European Union (EU) that Fiji will return to parliamentary government through an early election, and that the interim government will ensure the full restoration of basic human rights and fundamental freedoms as provided for in Fiji's constitution. The interim administration is now proposing an advisory National Council for Building a Better Fiji (NCBBF) to assist with the preparation of a 'People's Charter' as a blueprint for Fiji's future governance.

On 31 May 2007, the interim administration lifted the public emergency regulations that had been in place since the coup. However, it cautioned the people that it would continue to deal with anyone who incites public instability and disorder, under the Public Order Act.

As in the 1987 and 2000 coups, the takeover of the elected government resulted in very serious consequences for democracy, the rule of law, and the economy. There is also concern about its impact on race relations - especially between the two main communities, the Fijians and the Indians. With coups having resulted 
in the removal of three elected governments, people ask 'what is the point in having elections?'.

\section{The people's concerns}

Since the coup, people have observed that individuals and groups have been taken in by the military for interrogation under the provisions of the Public Emergency Decree. The military has done this to ensure public order and national security. But the people have been very concerned by allegations of human rights abuses. There have also been restrictions on freedom of expression and freedom of movement. The people have now realized that the protection in the constitution for their basic human rights and freedoms is not guaranteed in all circumstances.

The military and the interim administration have reminded people that anyone with human rights complaints should seek the assistance of the appropriate authorities. But the credibility of the Fiji Human Rights Commission as an independent and impartial body under the constitution has been seriously compromised by the stance taken by the Commission's director in relation to the coup. People's confidence in the independence and integrity of the judiciary has been undermined by the suspension of Chief Justice Daniel Fatiaki, and the long delay in the appointment of a tribunal to look into the allegations against him. An acting Chief Justice has been appointed, but the constitutionality of this is being challenged. There has also been speculation that the judiciary has been divided by factionalism. People have been concerned that the police force has been weakened by the loss of many senior staff, and also concerned about the delays in police investigations into coup-related cases, including the death of two individuals allegedly during or following their detention for interrogation.

The legality of the 2006 coup remains an issue. Everyone agrees that this is best left to the courts to determine. There are in fact three cases on this pending in the High Court; one by deposed Prime Minister Qarase and some of his deposed ministers; another by the dismissed chief executive of the Fiji Cane Growers Council, Jagnath Sami; and another by several members of the suspended GCC.

In the meantime, the people are confused about the status of Fiji's constitution and the compliance by the military and the interim administration with its provisions. The military has justified the coup on the ground of 'necessity'; the army felt it must act to safeguard the nation from what it perceived to be corrupt practices and race-based policies of the Qarase government. The military decided not to abrogate the constitution, but to maintain and to uphold it.

However, various actions by the military and the interim administration since 5 December 2006 have raised questions about whether or not they have, in effect, suspended certain provisions relating to the conduct of executive government, parliament, the judiciary, the public service and emergency powers. Another 
concern related to the law has been the perceived harassment and intimidation of people who have sought relief in the courts against the new regime. In this context, the people have welcomed the lifting of the Public Emergency Decree. Many, however, remain concerned whether or not this will lead to the full restoration of constitutional rights and freedoms. People are still wary that the Public Order Act might be used to curtail free movement and expression.

As regards the country's return to democracy, the people have been reassured by the interim administration's commitment to restore parliamentary government within three years. What is hoped for now is that it will announce firm timing for the elections, as it has been encouraged to do during on-going consultations with the Pacific Islands Forum and the EU. The Forum and the EU have been pressing for elections within two years.

In conjunction with preparations for the election, the people have supported moves by the interim administration to review and up-date constituency boundaries following the 2007 census. The interim administration has also announced its intention to review provisions in the constitution providing for community-based representation in Fiji's parliament. Whilst this is appreciated, the general feeling is that any review of Fiji's constitution should be considered as a separate and longer-term objective, so as not to delay Fiji's return to parliamentary democracy. The Fiji constitution itself has specific provisions covering procedures for its review. The interim administration can facilitate a constitutional review by identifying particular provisions and/or issues to be considered and the terms of reference for follow-up by the new parliament and government after the election.

One aspect of the institutional arrangement that has caused confusion is the direct and concurrent involvement of the military in the interim administration and the civil service. The people appreciate that it is interim Prime Minister Bainimarama's sole prerogative to decide whether to concentrate on his responsibilities as the head of government or on his responsibilities as the head of the RFMF.

What is considered important is for a clear separation of powers between, on the one hand, the military, and, on the other, the interim administration and the civil service.

In December 1987 the military facilitated such a separation of powers when it placed in office the all-civilian interim administration led by Ratu Sir Kamisese Mara. Again, in June 2000, the military put into office an all-civilian interim administration led by Laisenia Qarase.

As regards the civil service, the transfer to it, on professional merit, of military officers who have resigned from the RFMF is not new. It started in the British colonial service and has continued since independence in 1970. The RFMF was 
recognized as a very good source of well-trained and professionally experienced administrators. However, as in the wake of the 1987 and 2000 coups, it is important to ensure a clear separation between the military and the civil service. Those who have been seconded to the civil service need to consider the option of resigning from the military before they take up their new responsibilities. Such a clear separation between the military and the interim administration and the civil service will ensure that there is no confusion as regards lines of authority and accountability.

At the time of the 2006 coup, the immediate and general concern of the people was related to the loss of democracy. Today, what they are most anxious about is their economic security. The economic impact of the coup is serious. The contraction in the economy is continuing. This is despite the best efforts of the interim administration to reverse the decline and to guide the country back to sustained economic growth. In fairness to the interim administration, the fundamental economic problems in Fiji in the past few years - which have impeded economic growth - have been the lacklustre performance of the export sector, the continuing increases in imports of consumption goods, the high operating costs of government, and the persistent low levels of investment, especially foreign, private sector investment. The decline and stagnation in exports has resulted from the loss of special markets for garment exports, the fall in sugar and gold production, and the reduction in prices for Fiji sugar in the EU markets and the closure of the gold mine at Vatukoula. ${ }^{3}$

The interim administration has taken drastic measures to cut costs in the public service. New initiatives for increased exports in agriculture, fisheries and forests have been introduced. However, the best growth and investment sectors - the tourism and construction industries - have been hard hit by the decline in tourist visitor numbers and the general atmosphere of uncertainty following the coup.

The withdrawal by the interim administration of the Public Emergency Decree was an important milestone for the tourism industry. Hopefully, it will lead to the early removal of travel advisories, which have resulted in a decline in visitor numbers from key tourism markets, like Australia, New Zealand, the USA, Japan and the United Kingdom. The restoration of tourist visitor numbers will, in turn, enable Air Pacific to review its current reduced operation and resume all air services.

At the individual level, people in Fiji are feeling the very difficult economic conditions which have followed the coup. When jobs are lost, and salaries and wages are cut, there is a heightened feeling of insecurity, and the primary concern is about the survival of one's family. There is a growing sense of despair and anxiety about the future. Ultimately, it will be the assurances and commitments that the interim administration makes as regards the rule of law and the country's 
early return to parliamentary democracy that will greatly assist in restoring public confidence, and thus help to promote economic recovery.

\section{The nature of politics in Fiji}

In the main, life in Fiji is race-based: First come concerns for oneself and for one's ethnic or cultural community; second comes concern for Fiji. It is a reflection of cultural differences in religion, customs and values. Fijians consider their security from their point of view as the $i$ Taukei, or the host community, as landowners, and also as Christians.

Our Indian people, on the other hand, regard themselves as the tenant community and also as victims of all kinds of exclusion from government, the civil service, the military, government affirmative programs and the like - and of the coups of 1987 and 2000. Their concern for security has been heightened by the expiry of agricultural leases, and the declining number of Indians as a proportion of the population. For the other minorities, their sense of insecurity arises from a feeling of not being sure of their place in Fiji.

Politics in Fiji is based on race rather than differences in economic and social development policy. There is not, for example, one political party that advocates small government and a bigger role for the private sector, and another that favours big government and a role for the state in providing welfare assistance and support to the poor and the disadvantaged. Governments of all persuasions have generally been conditioned in their thinking by economists and bureaucrats that growth, high growth, and sustained high growth are the answers to Fiji's economic future. However, all governments have also supported high expenditure on assistance to the poor, through social welfare support and rural community development.

Fiji's political spectrum is characterized largely by extreme Fijian ethno-nationalism at the extreme of one side, and by pro-Indian activism at the periphery of the other side. The political centre represents those who believe in moderation, and a Fiji with an equal place and equal opportunities for all.

Fiji's prime minister from 1970 to 1987, Ratu Sir Kamisese Mara and his Alliance Party placed themselves from the outset at the political centre. Their policy was 'Fiji for All'. But Ratu Mara suffered politically from trying to hold onto the middle ground, first by his loss of Fijian support in the April 1977 election, and second in the election of May 1987, when he was deeply disappointed by what he felt was the lack of Indian appreciation of his multiracial policies. In 1987, Dr Bavadra, the prime minister in the Fiji Labour Party/National Federation Party (FLP/NFP) coalition, which won the election of that year, was not given the time to show where he stood. In 1992, the then prime minister, Sitiveni Rabuka, and his Soqosoqo ni Vakavulewa ni Taukei (SVT) party started as Fijian nationalists but, by 1997, Rabuka personally had moved to the political centre. 
In the same period, Jai Ram Reddy and his NFP started from somewhere at the centre. But like Rabuka, by 1997, Reddy had personally moved to the political centre. The result was, first, a positive achievement - the Fiji 1997 constitution - and, second, a negative consequence - they were both defeated at the May 1999 election.

As regards Prime Minister Mahendra Chaudhry (1999-2000) and Prime Minister Laisenia Qarase (2000-2006), I would say that they are two of the same kind in their approach to politics in Fiji. They both strategically placed themselves at the centre of their side of the political spectrum. As politicians, their basic instinct was to protect their ethnic support base. Their policies in government, therefore, tended to be orientated towards their ethnic political constituents. But, of course, they were also committed to national unity and multiracial cooperation. The result was their failure to reach agreement on routine and non-politically controversial changes to the constitution, or to resolve the complex issue of the Agricultural Landlord and Tenant Act (ALTA); and their reluctance to establish a multiparty cabinet, as required by the constitution. There was also a negative impact in regard to the differing perceptions they generated about their government's policy direction. As a result, Fijians perceived that Chaudhry and his government were too Indian oriented and therefore, racist; while Indians perceived that Qarase and his government were too Fijian oriented and therefore, racist. Such perceptions were a major cause of the coups of 2000 and 2006.

This is a generalized overview of the political situation in Fiji since independence. There is no intention to cast any doubt on the sincerity of all our leaders in their claim that multiracial cooperation is the way to long-term peace and unity in Fiji. What is at issue, however, is the political inclination of our leaders in their response to the interests and concerns of their respective ethnic communities.

\section{The implications of the $\mathbf{2 0 0 6}$ coup on race relations}

Anyone reading the daily 'Letters to the Editor' columns in Fiji would not fail to see the differences in viewpoints reflecting ethnicity. Many on the Indian side have openly expressed their support for the coup and the new regime. One suspects that these are people who hold very strong feelings about the coups in 1987 and 2000. In their view, Indians were the victims of the two earlier coups and Fijians were the main beneficiaries. (For their part, the Fijians were indeed the main supporters of the 1987 and 2000 coups.) As regards the 2006 coup, the majority of Fijians have been reserved and silent; the ousted Qarase government had been supported by more than 80 per cent of Fijian voters at the May 2006 election. Many people of all races have expressed their disappointment about the 2006 coup and the subsequent disregard for the rule of law and for Fiji's constitution. Fortunately, differences in ethnic perspectives towards the 2006 coup have not led to open racial confrontation. Nevertheless, they are a reminder that the promotion of national unity and cooperation among the different 
communities in Fiji must not be ignored: They must continue to be consciously supported and promoted. It is, suggested, therefore, that the interim administration gives priority to this in its proposed People's Charter, to be prepared by the National Council for Building a Better Fiji.

The interim administration can begin the process by initiating conciliatory dialogue with all political parties represented in the dismissed parliament. Promoting political reconciliation and cooperation would assist in creating a positive environment to facilitate not just speedy economic recovery but also a free and fair election. A political accord and consensus between all political parties that were represented in the last parliament would entail a binding agreement by all parties that the interim administration is to be supported in carrying out and completing its mandate from President Ratu Josefa Iloilo to return Fiji to parliamentary democracy.

In return, there would need to be agreement that those who have mounted legal challenges against what has happened would be allowed to continue to do so unhindered, in accordance with their constitutional rights. Also, members of the dismissed parliament would be financially compensated, subject to agreed conditions - as was done in 2000 by the interim administration at the time.

This comprehensive political accord would provide the necessary environment for a free and fair parliamentary election. Equally important would be the immediate positive impact of such an accord on restoring and lifting public and investor confidence. In times of adversity, such as that which Fiji is currently going through, all our leaders are called upon to exercise their power and leadership with even greater responsibility than usual for the greater good of our country.

As regards the proposal to review the constitution, and specifically the requirement for communal representation, any re-look at Fiji's constitution should also include an examination of the provisions relating to the formation of a multiparty cabinet (Section 99). The current provisions are simply politically unworkable. They work only if the entitled party is willing to accept the position of being a junior and unequal partner in the multiparty cabinet and in parliament. Fiji should, instead, build on the provisions of the compact chapter of the constitution (Section 6) and, in particular, the principle that in the formation of government, parties should consider joining in a voluntary coalition of willing political parties. This will be a genuine coalition of equal partners. This, in fact, was the kind of political understanding and cooperation that the two main proponents of the 1997 constitution, Sitiveni Rabuka and Jai Ram Reddy, entered into in the lead-up to the May 1999 election. They had agreed that, if their parties won at the polls, a Fijian would be prime minister and an Indian would be deputy prime minister. Had they won, they would have set a positive example for the 
adoption of this kind of intercommunity cooperation in other areas of government - such as the appointment of the President and the Vice-President by the GCC.

\section{The way forward}

With its commitment to promoting a non-racial Fiji, the interim administration now has the opportunity to secure greater political cooperation and understanding. The social justice chapter of the constitution (Section 44) ought also to be reviewed to clearly prescribe guidelines for affirmative action programs. Everyone agrees that the basic criterion for assistance should be the need of all disadvantaged and underprivileged individuals and groups, regardless of their ethnicity. In relation to expiring agricultural leases on native land under ALTA, attempts by previous governments to secure a resolution have been frustrated by political self-interest. Given its importance both for stimulating agricultural production and for intercommunity cooperation, the interim administration should consider legislation on this issue as part of its review agenda.

Changes and improvements in the constitution and in land legislation to facilitate greater cooperation among the communities in Fiji are important for a more facilitative legal framework. However, legislative action on its own is not enough. Patriotic feelings of national unity can only come from the heart. It is thus important for the interim administration to task its National Council for Building a Better Fiji to include programs for national reconciliation and unity in the proposed People's Charter. In this, Fiji should draw inspiration from the vision of Fiji's first prime minister, Ratu Sir Kamisese Mara. When accepting Fiji's formal instrument of independence on 10 October 1970, he told the Queen's Representative, HRH Prince Charles, that the people of Fiji were taking on the full responsibility of nationhood not only for themselves, but also for each other. Fiji is a country which, since independence, has continually been in search of its destiny as a multi-ethnic and multicultural society. Fiji's prime ministers and their governments have devoted themselves to efforts to realize this vision, but they have not succeeded. It is now for the interim administration to take up the challenge.

One of the great lessons of history is that people are confident and able to fully apply their creative abilities and energies when they are free - when there is no impediment to their enjoyment of their constitutional rights and freedoms. They are also confident when the law treats everyone equally and fairly, and when they are governed in the best collective interest. This is why there is a direct correlation between, on the one hand, democracy, the rule of law and good governance, and, on the other, economic dynamism. Repression, suppression and exclusion lead only to fear, frustration, lack of confidence, and economic decline and stagnation. This has been the experience not only of all liberal democracies but also of state socialist countries and nations with military regimes. Fiji has much to learn from this. 
The interim administration is to be commended for its commitment to building a better Fiji through a corruption-free and non-race-based approach to governance. However, for Fiji to make rapid progress in economic recovery, it must respond to the people's concerns that there be an early return to democracy, the rule of law, economic security and long-term peace, stability and unity. The Book of Ecclesiastes in the Old Testament tells us that, in the ultimate, life here on earth has no real purpose. Therefore, enjoy it, for it is like chasing the wind! Now I do not share this rather pessimistic view of life. Where there is life, there is hope to make it better - that is our hope for Fiji.

What we critically need today is national leadership by people who have the courage, the vision and the commitment to stand firmly at the political centre, and to make Fiji a country that believes in, and cares for, all its people. For the citizens of Fiji, what is needed is a new attitude in our relationships with one another. In our multi-ethnic and multicultural society, our religious faiths may be different, but they are all centred on a common belief in an Almighty God whose love embraces all of us and is infinite and is boundless. It is love with no condition. Let us extend and share that same love as the binding force that draws us together.

The challenge for us all is to build a Fiji that is united, progressive in its economic and social development, proud of its cultural diversity, and committed to the rule of law, good governance, and the protection of our God-given environment.

\section{ENDNOTES}

1 The 'other' communities, known in electoral terms as the 'general voters', are those who are neither ethnic Fijian, Indo-Fijian nor Rotuman. They include Europeans, part-Europeans, Chinese, and other Pacific islanders

2 Commodore Bainimarama's acceptance speech as Prime Minister, 6 January 2007, http://www.fiji.gov.fj/publish/printer_8177.shtml

3 The Australian company Westech Gold bought Vatukoula mine from Emperor Mines in 2007, was then taken over by River Diamonds, and resumed production. The workforce under the new arrangements was far smaller than it had previously been. 